\title{
TVET and Sustainable Growth in Developing Countries: Lessons from China
}

\author{
Osidipe Adekunle* \\ Research Center for China Africa Education Cooperation, China
}

ISSN: 2637-7659

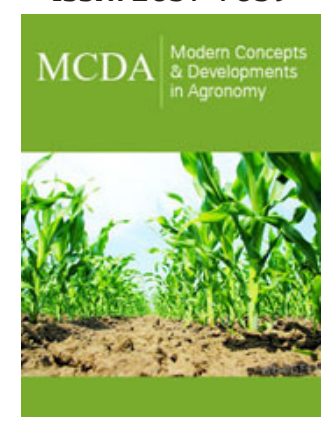

*Corresponding author: Osidipe Adekunle, Research Center for China Africa Education Cooperation, Institute of African Studies, China

Submission: 監June 21, 2019

Published: 佔July 03, 2019

Volume 4 - Issue 5

How to cite this article: Osidipe A. TVET and Sustainable Growth in Developing Countries: Lessons from China. Mod Concep Dev Agrono.4(5). MCDA.000597.2019.

DOI: 10.31031/MCDA.2019.04.000597

Copyright@ Osidipe Adekunle, This article is distributed under the terms of the Creative Commons Attribution 4.0 International License, which permits unrestricted use and redistribution provided that the original author and source are credited.

\section{Opinion}

Technical and Vocational Education and Training (TVET) has been a front burner and controversial topic in many developing countries as a result of the existing diverse perspectives on its feasibility or effectiveness in terms of provision of education and the attendant benefits. The embedded diverse interests involved in TVET ranging from the policy makers in host countries to international organizations involved in TVET as well as researchers from the two divides of the funding countries and fund recipient countries. The prevalent arguments against the feasibility of TVET as an option to academic stream of studies in developing countries has dominated the global scene for long until the recent renewed focus on the subject by international organizations, notably the World Bank and traditional donor agencies. The latter had hitherto deserted TVET in preference for regular academic stream of studies consequent upon the World Bank funded research recommendations that investment in TVET has lower rates of return in comparison to the regular academic education. Among others, researches conducted by World Bank researchers in the early 90s reviewed the African vocational education experience and returned with results vocationalization initiatives prompted by post-independence aspirations all failed due to issues related to high cost, lack of student interest, or mis-match with employers needs and several other problems.

The results and recommendations of several of such studies significantly influenced the decision of the World Bank and other international funding organizations on provision of funds for TVET in developing countries and resulted in the drastic reduction of the World Bank's lending to vocational education which stood at $25 \%$ out of the total education lending in 1984-1985 to 3\% by 1996. The World Bank hinged its decision to significantly cut its funding of TVET projects coupled with its related policy advice to governments to reduce their financial support and provision of TVET on the proposition that the governance, funding and provision of TVET is best left to individuals, enterprises, and private sector training institutions with government intervention kept to a minimum. The Bank's decision adversely affected the growth of TVET in most developing countries; especially, in Sub-Sahara Africa considering the fact that most of the countries newly got independence and were unable to fully finance TVET provisions effectively without external lending. Though the Bank's decision received diverse criticisms, and it took over three decades later before an apology came from the Bank during its 2018 annual meeting, the nascent growth of TVET in most African countries after their independence was effectively truncated by the Bank's decision, which was followed by years of prevalent imbalance in education structure, underfunding of TVET, skills shortages, skills mismatch and massive unemployment coupled with stagnant economies on the African continent. On the other hand, China, the largest developing country in the world, has become a model for many other developing countries seeking space in the global economy. As a developing country that has attained rapid development through investment in TVET in contemporary period, China remains a feasible and most appropriate example for developing countries intending to promote inclusive growth and development. The Chinese successful experience in TVET at the time when theories postulated by westernfunded researchers claimed investment in TVET was not profitable especially for developing countries, gives credence to the need for developing countries to learn and replicate same. China's successful experience in TVET delivery is the most recent, globally acknowledged successful TVET delivery project which effectively solved the twin-problem of unemployment 
and unemployment-triggered poverty: two grim challenges confronting most developing countries of the Southern hemisphere. China's consistent rise to global limelight as a leading industrial nation no doubt is closely connected to the country's unwavering focus on human capital development through the provision of education that is relevant to the need of the society at every stage of development.

Within three decades, the country has transformed into a global manufacturing base, and experienced structural transformations in the economy as the share of agriculture output and employment significantly declined in favour of industry and services. Between 1990 and 2015, the percentage of the population employed by agriculture declined significantly from $60.1 \%$ to $28.3 \%$. On the other hand, the population employed in the manufacturing (secondary sector) and services (tertiary industry) sectors of the economy increased to $29.3 \%$ and $42.4 \%$ respectively. The gradual drop in the employment proportion in primary industry and steady rise in the employment proportion in the secondary (manufacturing) and tertiary (services) industries signals significant increment in the number of skilled manpower available for employment in the latter two sectors. Furthermore, due to the continued growth in socio-economic development, the living conditions of the general population continues to rise with corresponding increase in the number of residents living in cities (not due to rural -urban migration, but due to the transformation of hitherto rural areas

Table 1: Percentage of urbanization level in China. into modern cities) (Table 1). The country experienced clear shift from an agricultural and primary goods-based economy of the pre- reform and opening up period to an industrialized economy combined with highly efficient service economy. This does not mean that China abandoned agriculture, because the industry still employs a large portion of China's active work force with a little over 300 million people employed in 2008. The agricultural sector has witnessed significant improvement and higher productivity than the pre- reform era. The manufacturing sector is the key contributor to the country's employment and GDP, it is the main driving force behind the Chinese economic growth. TVET in China has significantly served as a tool for the promotion of rural and agricultural development in the country. The implementation of $11^{\text {th }}$ five-year national development plan witnessed various levels of technical and vocational education providing job training for 185 million farm laborers for employment. More than $60 \%$ of vocational school graduates in China find jobs in local areas. It is pertinent therefore, for developing countries to re-position TVET to focus on the development of the agriculture, industry and manufacturing industry in a phased sustainable development process adopted by China. Successful TVET delivery for sustainable development as seen in China, must have active involvement of the State as the major provider coupled with significant amount of incentives to make TVET attractive to students and parents. With this, the path to a stable, steady and inclusive growth and development can be assured.

\begin{tabular}{|c|c|c|c|c|c|c|c|c|c|}
\hline $\mathbf{1 9 7 8}$ & $\mathbf{1 9 9 0}$ & $\mathbf{1 9 9 5}$ & $\mathbf{2 0 0 0}$ & $\mathbf{2 0 0 4}$ & $\mathbf{2 0 0 6}$ & $\mathbf{2 0 0 8}$ & $\mathbf{2 0 1 0}$ & $\mathbf{2 0 1 2}$ & $\mathbf{2 0 1 4}$ \\
\hline 17.9 & 26.4 & 29.04 & 36.22 & 41.76 & 43.9 & 44.9 & 50 & 53 & 55 \\
\hline
\end{tabular}

For possible submissions Click below: 